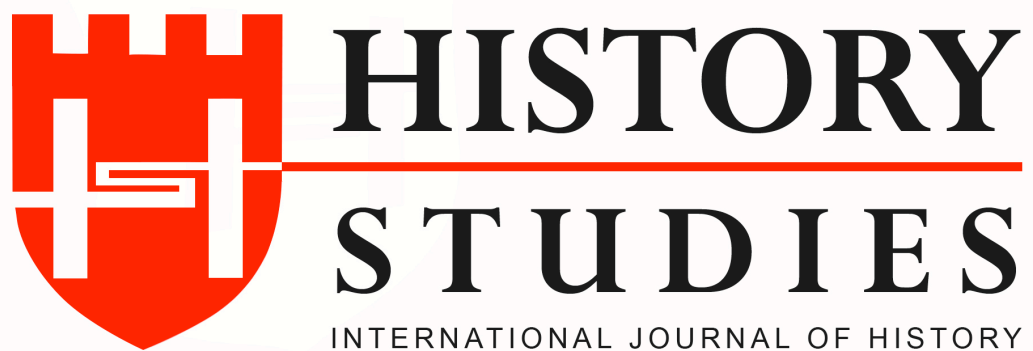

ISSN: 13094173 (Online) 1309 - 4688 (Print)

Volume 11 Issue 3, June 2019

DOI Number: 10.9737/hist.2019.753

Araştırma Makalesi

Makalenin Geliş Tarihi: 11.04.2019 Kabul Tarihi: 25.04.2019

Atıf Künyesi: Alpaslan Öztürkci, "Parti İçi İktidar Mücadelesi Bağlamında Demokrat Parti'de Parti Muhalefetin Araçları (1946-1950)", History Studies, 11/3, Haziran 2019, s. 1059-1074.

\title{
Parti İçi İktidar Mücadelesi Bağlamında Demokrat Parti’de Parti Muhalefetin Araçları (1946-1950) ${ }^{1}$
}

\section{Intra-party Opposition's Tools in the Democratic Party in terms of Intra-party Power Struggle}

\author{
Dr. Alpaslan Öztürkci \\ ORCID No: 0000-0003-2877-8415 \\ Milli Ĕgitim Bakanlığ
}

\begin{abstract}
Öz: Demokrat Parti, geniş heteredoks bir kitleyi bünyesinde toplayarak kurulan bir siyasal partidir. Parti'nin bir koalisyonu andıran yapısı, parti içi muhalefet açısından oldukça geniş olanaklar taşımaktaydı. Demokrat Parti'nin muhalefet yıllarında(1946-1950) parti içi muhalif unsurlar, Demokrat Parti kurucularının siyasal geçmişlerini, muvazaa iddialarını ve 12 Temmuz Beyannâmesi'ni araçsallaştırarak partinin merkez yönetimine sert eleştiriler yönelttiler. Çalışmada Başbakanlık Cumhuriyet Arşiv Belgeleri ve dönemin basını ile modern literatür taranarak parti içi muhalefetin tezlerine ve kurucuların anti tezlerine yer verildikten sonra senteze ulaşılmaya çalışılmıştır. Çalışmada şu tez savunulmaktadır: Parti içi iktidar savaşını kurucuların kazanmasında etkili olan temel faktör, parti içi muhalefetin siyasal gerçeklikten kopuk politikaları karşısında kurucuların rasyonel politikalar geliştirebilmiş olmasıdır.
\end{abstract}

Anahtar Kelimeler: Parti İçi Muhalefet, Kurucular, Muvazaa, 12 Temmuz Beyannâmesi, Parti İçi iktidar

\begin{abstract}
Abtract: The democratic party is a political party that includes cosmical heterodox populace. It provided many oppartunities in terms of intra-party opposition movements thanks to its analogic forming a coalition. The intra-party opposition factors panned to the centre management during the opposition years (1946-1950) by instrumentalizing party's founders political background, simulation claims and 12 July declaration. In this studies after widely searching The Prime minister Republic Archive Documents, the press of the period and the modern literature, we handled party's interior opposition thesis and the founders antithesis and after that We reached our synthesis. This survey defends the most essential factor that is why the party's founders won the intra-party power struggle is the founders could develop rational politics against intra-party opponents unreal and irrational politics.
\end{abstract}

Key Words: Intra-party Opposition, Founders, Simulation, 12 July Declaration, IntraParty Centralized Power.

\footnotetext{
${ }^{1}$ Bu çalışma Akdeniz Üniversitesi Sosyal Bilimler Enstitüsünde Nisan 2019 tarihinde kabul edilen "Demokrat Parti'de Parti İçi Muhalefet (1946-1950)" başlıklı çalışmadan üretilmiştir.
} 


\section{Giriş}

Siyasal partilerde parti içi iktidarı ele geçirme ya da onu etkileme hedefi taşıyan hareketlerin tamamı, parti içi muhalefet olarak tanımlanabilir. Çoğulcu-demokratik sistemlerde marjinal partileri bir kenara bırakırsak siyasal yelpazenin merkezine yakın her parti az çok "Hepsini Yakala (Catc Hall)"2 partisine dönüşerek iktidara gelmeye ya da ondan pay almaya çalışır. Bu da siyasal partiler içinde ideolojik-düşünsel bir ayrılığı işaret eden farklı kanatların ya da şahsiyat(sen-ben) kavgalarına dayanan hizip kliklerinin ortaya çıkması anlamına gelir. Kanat ve hiziplere öncülük eden gruplar da sıkı bir kişisel dayanışmayla hareket eden "Camarillalar", karizmatik bir liderin öne çıktığı "Klanlar", genellikle genç kuşakların temsilcilerinin yer aldığı ve grup içinde nisbi eşitlik ve yatay ilişkinin ön plana çıktığı "lider takımları" şeklinde ayrılabilir. ${ }^{3}$

Bir siyasal partide parti içi muhalefetin araçları ise partinin yapısına, ideolojisine ve konjonktüre göre değişkenlikler gösterir. Tek parti iktidarına karşı bütün muhalif kesimleri çatısı altında toplayan Demokrat Parti'de de daha çok partinin bir koalisyonu andıran yapısından kaynaklı ve görünür sebebini iktidara karşı uygulanacak politikaların yöntemi konusundaki ayrılıkların oluşturduğu çatışmalar baş göstermeye başladı. Partideki söz konusu tartışmaların asıl nedenini ise parti içi iktidar mücadelesi oluşturur. Lider takımlarındaki yatay ve eşitlikçi ilişkiye benzer tarzda örgütlenen parti içi muhalefetin önde gelen isimleri; İstanbul İl Başkanı Kenan Öner, Demokrat Parti listelerinden bağımsız aday olarak İstanbul milletvekili seçilen Mareşal Fevzi Çakmak, Afyon Milletvekili General Sadık Aldoğan, Kütahya Milletvekili ve Genel İdare Kurulu(GİK) Üyesi Ahmet Tahtakılıç, partinin Orta Anadolu ve Karadeniz teşkilatlanmasının önemli ismi Osman Bölükbaşı ${ }^{4}$ gibi isimler, kurucuların siyasal geçmişlerini, muvazaa iddialarını ve 12 Temmuz Beyannâmesi'ni araçsallaştırarak parti içi iktidarı ele geçirme mücadelesine başladılar. Buna karşın Celal Bayar, Adnan Menderes, Fuat Köprülü ve Refik Koraltan'dan oluşan kurucular ise "Camarillalar" tarzında hareket ederek kişisel bağlılıklarını ön plana çıkararak birlikte hareket ettiler ve parti içi muhalefetin hamlelerine karşı parti içindeki iktidarlarını korumaya çalışıılar.

\section{Parti İçi İktidar Mücadelesi Bağlamında Muvazaa İddiaları}

Muvazaa, Demokrat Parti kurucularının Cumhurbaşkanı İnönü’yle anlaşarak kontrollü muhalefet yaptıkları böylece de danışıklı dövüşle CHP iktidarının devamına hizmet ettikleri savlarına dayanır. Nurettin Ardıçoğlu'nun Kudret gazetesinde yer alan şu görüşleri parti içi muhalefetin bu konudaki düşüncelerini derli toplu olarak özetlemektedir: "Memlekette başlamış olan demokrasi inkılabı soysuzlaştırılmış ve halk kitlelerinin üç seneden beri yaptığı büyük mücadele akim bırakılmıştır. Bunun sebebi, muhalefetin başında bulunan bir kliğin iktidara ram olması ve yine aynı klik muhalefetin bünyesinde tahakküm ve Makyavelizm yoluna sapmasldir. ",

Yukardaki metinde yer aldığı gibi parti içi muhalefetin, sıklıkla davayı İnönü'ye satmakla suçladığı kurucuların işini zorlaştıran iki temel olgudan söz edilebilir: İlki, 1930 yılında güdümlü muhalefet partisi olarak kurulan Serbest Cumhuriyet Fırkası(SCF) ile Demokrat Parti'nin kuruluş sürecindeki benzerliklerdir. SCF programı nasıl Atatürk'ün

\footnotetext{
${ }^{2}$ Andrew Heywood, Siyaset, (Çev. B. Özipek, B. Şahin, M. Yıldız, Z. Kopuzlu, B. Seçilmişoğlu, A.Yayla), Adres Yayınları, Ankara, 2013, s. 322; Tanju Tosun-Gülgün Erdoğan Tosun, Türkiye'de Siyasal Parti Üyeliği ve Katılım, Kalkedon Yayıncilık, İstanbul, 2010, s. 10.

3 Maurice Duverger, Siyasal Partiler, (Çev. Ergun Özbudun), Bilgi Yayınevi, İstanbul, 1974, s. 211.

${ }^{4}$ Samet Ağaoğlu, Aşina Yüzler, Yapı Kredi Yayınları, İstanbul, 2011, s.49, 147; Cihad Baban, Politika Galerisi, Timaş Yayınları, İstanbul, 2009, s. 87.

5 “Muvazaayı Doğuran Amil Nedir", Kudret, 28.08.1948.
} 
onayından geçmişse DP programı da en azından ilkesel düzeyde İnönü’nün onayından geçmiştir. DP kurulmadan önce Bayar ile İnönü arasında şöyle bir konuşma geçtiği siyasal çevrelerde bilinmektedir;

İnönü Demokrat Parti programını alarak Celal Bayar'a sorar:

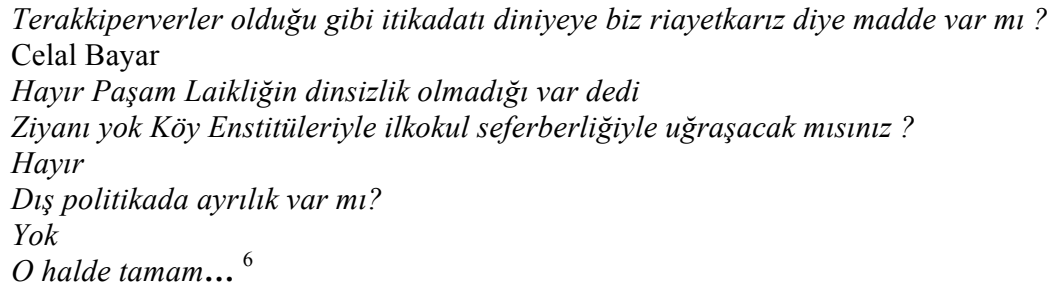

Heper, bunlara Atatürk'e karşı düşmanca bir politika izlenip izlenmeyeceği ve meclisin saygınlığının korunup korunmayacağı sorularını da ekler. ${ }^{7}$

Kurucuların işini zorlaştıran ikinci olgu ise DP'nin kuruluş aşamasında ve muhalefet yıllarının ilk aylarında "iktidarın gösterdiği gayretkeşlik"tir. Bayar'ın ifadeleriyle söylersek kurucular, bu süreçte "iktidar partisinin geniș bir müsamahası ve hatta teșviki ile karşılaşmıștır. ", $\mathrm{Bu}$ bağlamda İnönü, Demokrat Parti'nin kuruluş sürecinde sürekli kurucuları cesaretlendiren konuşmalar yaptı. Parti'nin kurulmasının ardından kuruculara hemen mecliste çalışmalarını yürütebilecekleri uygun koşullar iktidar partisi tarafından sağlandı. ${ }^{9}$ Yeni partiye kuruluşunun ilk aylarında iktidar partisi yöneticilerinden ve yayın organlarından hemen hemen hiç eleştiri gelmedi.

Bu sağlam zemin üzerinde yoğun bir propaganda faaliyeti yürüten parti içi muhalefetin önemli siyasal argümanı ise şu isnatlar oluşturmaktadır:

1- Köprülü, parti sırlarını Nihat Erim kanalıyla İnönü’ye ulaştırmaktadır.

2- Hamdullah Suphi Tanrı̈ver'in 3 Nisan 1948 tarihli Tasvir'de yayımlanan "Demokrat Parti” başlıklı makalesi, muvazaanın açık delilidir.

3- 12 Temmuz Beyannâmesi'nin yayınlanmasından sonra Cumhurbaşkanı'nın doğu gezisine Demokrat Parti'den Nuri Özsan'ın katılması, muvazaayı işaret eder.

Parti içi muhalefetin Köprülü-Erim ilişkileri bağlamında muvazaa iddialarını yoğunlaştırdığı, somut konu CHP iktidarına ve Cumhurbaşkanı İnönü'ye en sert eleştirileri yönelten Demokrat Partililerden olan Afyonkarahisar Milletvekili Sadık Aldoğan'ın 18 Aralık 1947 tarihinde yapılan genel idare kurulu toplantısında sorgulanmasının Köprülü tarafından Erim'e aktarıldığ 1 suçlamalarıdır. ${ }^{10}$ Parti içi muhalefetin iddiasına göre Köprülü, daha toplantı bitmeden Erim'e telefonda, "Sadık Aldoğan'ın hesabını görüyoruz Yusuf Kemal vesairenin de hesabını göreceğiz",ll demişti. Bu iddiaları güçlendiren bazı somut deliller de söz konusuydu.

\footnotetext{
${ }^{6}$ Metin Toker, Tek Partiden Çok Partiye (1944-1950), Bilgi Yayınevi, Ankara, 1998, s. 81.

${ }^{7}$ Metin Heper, Türkiye'nin Siyasal Hayatı, Doğan Kitap, İstanbul, 2011, s.179.

${ }^{8}$ Kenan Öner, Siyasi Hatıralarım ve Bizde Demokrasi, Osmanbey Matbaas1, İstanbul, 1948, s.22; Orhan Mete, Bütün Tafsilat ve Akisleriyle Demokrat Parti'nin 1'nci Büyük Kongresi 7 Ocak 1947, Ticaret Dünyası Matbaası, İstanbul, 1947, s. 37.

9 "Demokrat Parti İşe Başlamadan", Ulus, 18.01.1946

${ }^{10}$ Nahit Saçlıoğlu, Bir Özgürlük Savaşçısı: Sadık Aldoğan, 1990, s. 25.

11 "Demokrat Parti Genel İdare Kurulunun 10.02.1948 Tarihli Toplantı Zabıtları", Samet Ağaoğlu, Siyasi Günlük: Demokrat Partinin Kuruluşu, (yay. haz. Cemil Koçak), İletişim Yayınları, İstanbul, 2013, s. 530.
}

\section{History Studies}


Demokrat Parti Genel Sekreteri Basri Aktaş, Kütahya Milletvekili ve GİK Üyesi Ahmet Tahtakılıç'a toplantı günü Köprülü ve Erim arasında "iyi güzel” ifadelerinin geçtiği bir konuşmaya şahit olduğunu anlatmıştır. Yine GİK Üyesi Yusuf Kemal Tengirşenk de Erim'e bu bilgileri Köprülü'nün aktardığını bildirir. ${ }^{12}$ Samet Ağaoğlu ise Celal Bayar'ın kendisine; Erim işinde Köprülü’yü savunmanın zor olduğunu ve Köprülü’yü kırmadan uyarmak gerektiğini söylediğini ifade eder. Bu konudaki parti içi muhalefetin söylem düzeyini aşan somut bir gerçeklik Sadık Aldoğan'ın sorgulandığı genel idare kurulu görüşmelerinin bir gün sonra CHP'nin yayın organı Ulus'ta yayımlanmasıdır.

İddialar karşısında sert reaksiyonda bulunan Köprülü, hafif meşrep olmadığını, Erim ile aralarında geçen konuşmanın Maarif Encümen'inde komünist hocalar konusuyla ilgili olduğunu ve Erim'in kendisine; “Arkadaşlar buraya gelmenizi rica ediyor. Bir de mebusların hocalık yapma meselesi vardır. Bunları görüşmek konusunda mutabık misınız, dedi. Ben de Iyi güzel dedim" şeklinde olduğunu açıklamıştır. ${ }^{13}$ Adnan Menderes, Demokrat Parti'nin muhalefet yıllarında hemen hemen her konuda olduğu gibi bu isnatlar karşısında Köprülü'nün yanında yer almıştır. Menderes, Köprülü-Erim görüşmesi sırasında Köprülü’nün yanında olduğunu ve kendisinin de Nihat Erim'in yanında bulunan Said Odyak ile konuştuğunu ifade etmiştir. Ulus gazetesinde yer alan haberlerle ilgili olarak ise haberlerin gazetenin yorumları olduğunu ve benzer haberlerin iktidara muhalif çizgide yayın yapan Vatan gazetesinde de yapıldığını hatırlatmıştır. ${ }^{14}$ Menderes ve Köprülü'nün söz konusu argümanlarına rağmen GİK üyesi ve kuruculara yakın bir siyasi figür Samet Ağaoğlu'nun ifadesiyle: "Parti içinde hemen hemen herkes bu haberlerin Köprülü tarafindan Erim'e aktarıldığından emindir. ${ }^{15}$

Parti içi muhalefetin Köprülü üzerinden muvazaa iddialarını gündeme getirmesi oldukça rasyonel bir stratejiye dayanır. Başka bir ifadeyle parti içi iktidarı ele geçirmek isteyen muhalifler için Köprülü en kolay hedeftir. Zira Köprülü laubali, küfürbaz, kibirli yapısıyla parti içinde en sevilmeyen kurucudur. ${ }^{16}$ Köprülü'nün bu yapısıyla Meclis Grubu'nun tamamının antipatisini kazanmakta hiç zorlanmadığını 1946-1948 kesitinde yapılan Meclis İdare Heyeti Seçimleri açıkça ortaya koymaktadır. Ağustos 1946 'da yapılan seçimlerde grubun büyük oranda oyunu alan Köprülü, Bayar'ın grup başkanı olduğu seçimlerde başkan vekili seçilmiştir. ${ }^{17}$, Kasım 1947 'deki grup başkan vekilliği seçimlerinde ise 38 oydan 21 'ini alarak yerini zor koruyabilmiş ${ }^{18}, 1948$ yılında yapılan son oylamada sadece 1 oy alabilmiştir. ${ }^{19}$

Demokrat Parti, kuruluşundan sonra iktidar-muhalefet ilişkilerinde tansiyonun yükseldiği zamanlarda iki partiye de yakın bazı aktörler tansiyonu düşürmek için aracılık etmekteydi. Hamdullah Suphi Tanrı̈ver de bu şahıslardan biridir. Bu sebeple kurucularla Hamdullah Suphi'nin birlikte görülmesi basında uzlaşı arayışı olarak sunulmaktaydı. Örneğin; 1947 yılının Ağustos ayında Hamdullah Suphi'nin Ankara Palas Oteli'nin bahçesinde kurucularla görülmesini Cumhuriyet gazetesi iki partiyi uzlaştırma çabaları şeklinde

\footnotetext{
${ }_{12}$ Ağaoğlu, Siyasi Günlük: Demokrat Partinin Kuruluşu, s.116, 540.

13 "Demokrat Parti Genel İdare Kurulu'nun 14.02.1947 Tarihli Toplantı Zabıtları", Ağaoğlu, Siyasi Günlük: Demokrat Partinin Kuruluşu, s.540-541.

14 “Demokrat Parti Genel İdare Kurulu'nun 14.02.1947 Tarihli Toplantı Zabıtları”, Ağaoğlu, Siyasi Günlük: Demokrat Partinin Kuruluşu, 540.

${ }_{15}^{15}$ Ağaoğlu, Siyasi Günlük: Demokrat Partinin Kuruluşu, s. 103,122.

16 "Ahmet Kemal Silivrili 'den Sonra Bir DP Milletvekili Daha İtham Ediyor", Yeni Sabah, 19.02.1948;

"Demokrat Partide Buhran ", Akşam, 08.02.1948;

17 “DP Meclis Grubu Dün Toplandı", Cumhuriyet, 07.08.1946.

${ }^{18}$ Adnan Ferruh Pancaroğlu, Yakın Tarihimizde Millet Partisi Olgusu(1948-1977), Yayınlanmammış Yüksek Lisans Tezi, Afyonkarahisar Kocatepe Üniversitesi, 2006, s. 7.

19 "Demokrat Partide Buhran ", Akşam, 08.02.1948; Piraye Bigat Cerrahoğlu, Demokrat Parti Masall, Milliyet Yayınları, İstanbul, 1996, s. 33.
} 
kamuoyuna aktarmaktayd ${ }^{20}{ }^{2}$ Parti içi muhalefet için ise bu ve benzeri fotoğrafların anlamı muvazaaya kuvvetli delil niteliği taşıdığı yönündeydi. Bütün bunların üzerine bir de Hamdullah Suphi'nin kurucular Bayar, Menderes, Köprülü ve Koraltan'a sorduğu bazı sorulara aldığ cevapları Tasvir gazetesinin 3 Nisan 1948 tarihli nüshasında, "Demokrat Parti" başlıklı makalesinde yayınlaması parti içi muhalefetin muvazaa iddialarını yoğunlaştırmalarına yetti. $\mathrm{Bu}$ konuda Tanrı̈̈ver'in kuruculara sorduğu ve cevaplarıyla beraber makalesinde yer verdiği iki kritik soru ve cevapları şöyledir:

\section{-CHP'nin sarsılmasinı, devrilmesini istiyor musunuz?}

-Bunu istemek kendi felaketimize çalışmaktır. CHP'sini tek parti kalmakla itham ettik, şimdi biz onun ylkılmaslyla tek parti olarak kalacaksak mücadelemizin meşru bir istinat noktası olduğunu iddia edebilir miyiz? CHP'den bir tek şey istiyoruz; Cumhuriyeti ilan ettiren sebeplere sadık kalsin bu esaslara göre memleketi idare etsin ve bizim üzerimizden basklyı kaldırarak murakabe vazifesi görmemize imkân bıraksın.

-Devlet Siyasetinde bir tebeddül (değişim) zihninizde bir yer tutuyor mu?

-Hayır, şimdiki devlet reisi tarihi klymetleri ve vazifeleriyle bir hakem mevkiinde görmek isteriz. Mazisi buna müsaittir. Böyle bir vazife için lazım olan şartların onda, başkalarından daha fazla mevcut olduğuna kaniyiz. Anayasanın derpişs ettiği usuller haricinde devlet riyasetinde bir tebeddüle taraftar değiliz. ${ }^{21}$

Kurucuların cevaplarında öne çıkan vurgu çoğulcu-parlamenter demokratik sistemin

HISTORY devamı için elzem olan muhalefete iktidara gelebilmesi için iktidarla eşit şartların sağlanması ve cumhurbaşkanının tarafsızlığının sağlanması hususlarıdır. Kurucular bu koşulları sağlama noktasında hukuk içinde kalarak mücadele edeceklerini, CHP'ye düşmanlık beslemeyeceklerini ve İnönü’nün hakemliğine razı olduklarını belirtmekteydiler. Kuşkusuz bu yaklaşım konjonktörün zorlamasıyla pragmatik sebeplere dayanmaktaydı. Konuşmanın geçtiği 1947 ortalarında Demokrat Parti halen varlı̆̆ını sürdürebilmek için iktidarın özellikle de Cumhurbaşkanı İnönü'nün müsamahasına ihtiyaç duymaktaydı. Bu durum kurucular açısından yaşamsal bir meseleydi ve iktidarla en azından belli bir eşgüdüm yakalamak zorunda olduklarının farkındaydılar. Ancak parti içi muhalefet bu koşulları muvazaanın bir delili olarak sundu ve DP kurucularının Tanrı̈̈ver vasıtasıyla Cumhurbaşkanına CHP iktidarını yıkmayacakları yönünde garanti verdiği tezini yoğun bir şekilde işlediler. Tabii Hamdullah Suphi'nin bütün bu iddiaları "iğrenç, adi bir iftira" olarak tanımlaması da ${ }^{22}$ parti içi muhalefetin performansını etkilemedi.

12 Temmuz Beyannâmesi’nden sonraki 1lımlı siyasal iklimde İsmet İnönü’nün doğu gezisine DP milletvekillerinden Nuri Özsan'ın katılması Demokrat Parti içinde başka bir tartışma ortamı doğurmuştur. Zira Özsan'ın parti adına davete katılması ${ }^{23}$ başlangıçta parti içi muhalefetin önde gelen isimleri tarafindan da desteklenirken daha sonra parti içi iktidar savaşının kızıştığı bir konjonktürde parti içi muhalefetin aracına dönüştürüldü. Nuri Özsan, Demokrat Parti II. Büyük Kongresi'nde kendini şu sözlerle savunmuştur: “Bu muvazaa denilen şey tamamen iftiradir. Ĕger böyle şey olsa idi herkesten evvel benim hissetmem ve duymam

\footnotetext{
20 “İki Partiyi Uzlaştırma Teşebbüsü Şayiaları”, Cumhuriyet, 07.08.1946.

21 "Demokrat Parti", Tasvir, 03.04.1948.

22 “Muvazaa İddiasına Dair”, Ulus, 04.09.1948; "Hikmet Bayur Hamdullah S. Tanrı̈vere Cevap Veriyor”, Kudret, 26.08.1948.

${ }^{23}$ Cem Eroğul, Demokrat Parti Tarihi ve İdeolojisi, Yordam Kitap, İstanbul, 2014, s.48; Ercan Haytoğlu, "İnönü Döneminde Türkiye'de Siyasal Yaşam”, (ed. Süleyman İnan ve Ercan Haytoğlu), Yakın Dönem Türk Politik Tarihi, Ankara, 2011, 96.
}

\section{History Studies}


tabii idi, ilk isyan edecek arkadaş ben olacaktım! Gayrimeşru harekete vasıta yapmak isteyen kim olursa olsun, evvela karşısına ben dikilirdim. Genel Kurul ehemmiyetle bana bu vazifeyi verdi. Partiyi küçük düşürme șerefini koru dediler. Böyle bir direktif veren kimseler muvazaa yapan kimseler olabilir mi? bütün bunlar sizin içinize, vesvese ve tereddüdün klzgın demirle dağlamak için kurulmuş bir tuzaktır. Bu sesler hepimizin takdir edersiniz ki mezar kazıcıların kazma kürek sesidir. Kongrenin sözü beyhude gayretin mezarcl demekten başka bir şey olmayacaktt." ${ }^{24}$

Nuri Özsan yukardaki ifadelerinde açıkça görüldüğ̈̈ bu iddiaları reddederek kendisini araçsallaştırırak yapılmaya çalışılan muvazaa isnatlarının partiyi parçalama gayesi taşıdığını ortaya koymaktadır. Bu konuda ilginç olan ise Nuri Özsan'1 "muvazaa emir eri",25 yakıştırmasıyla suçlayan Ahmet Tahtakılıç, Ahmet Oğuz gibi bazı GİK üyelerinin kurulun 10 Eylül 1947 tarihinde yaptığı toplantıda Nuri Özsan'ın geziye katılması kararını desteklemeleridir. ${ }^{26} \mathrm{Bu}$ paradoksal yaklaşımları sebebiyle daha sonra Bayar, bu şahısları bedbahtlıkla suçlayacaktır. ${ }^{27}$

Muhalefet yılları boyunca hiç eksik olmayan muvazaa iddiaları, Demokrat Parti’yi çok yıpratsa da 14 Mayıs 1950 Genel Seçimleri'yle iktidara yürüyüşünü engelleyememiştir. Bunda başlıca üç unsurun etkili olduğu söylenebilir: Birincisi; Celal Bayar'ın başarılı bir retorikle parti içi muhalefeti ve iktidar partisini özdeşleştirmesidir. Böylece Bayar, muvazaa iddiaları da dahil olmak üzere parti içi muhalefetin parti merkez yönetimini ele geçirmek için giriştiği her hamlenin iktidarın işini kolaylaştırdığını partisinin yerel teşkilatlarına ve tabanına kolaylıkla anlatabilmiştir. Bir yandan partinin Meclis Grubu'nu iktidarın karşısına dikerken kendisi de çıktığ 1 yurt gezilerinde iktidara yönelik sert eleştirilerde bulunuyordu. Örneğin; Bayar, Mart 1948'de Erzincan'da konuşurken muvazaa iddialarında bulunanları "çaresizlik ve mantısızlık" içinde olmakla suçluyordu. ${ }^{28} 7$ Eylül 1948 tarihli İstanbul konuşmasında ise SCF deneyimiyle muvazaa iddiaları arasındaki pozitif korelasyonun önüne geçebilmek amacıyla "1950 yllına kadar böyle giderse millete mesuliyetler onlara ait olmak üzere mukaddes haklarını bizzat koruyun diyeceğiz. Neticesini onların düşünmesi gerekir" demekteydi. ${ }^{29}$

Bayar, TBMM'de ve Çeşme Mitingi'nde benzer içerikli iki konuşmayla da muvazaa iddialarını tekrar reddetmiș ancak iktidarla ilișkilerde "Așiret reislerinin birbirine küsmesi gibi bir mücadele yolunu",30 tercih etmeyeceklerini beyan etmiştir. Eylül 1948'de Bayar muvazaa iddialarını etkisizleştirmek amacıyla, 1950 genel seçimleri öncesinde seçimlerde hilenin önlenebilmesi için Adalet ve İçişleri Bakanlıklarının Demokrat Parti'de olduğu bir koalisyon hükümeti önerisinde bulunmuştur. ${ }^{31}$

Demokrat Parti’nin iktidara yürüyüşünde muvazaa iddialarını zayıflatan ikinci etken iktidarın muhalefete karşı geliştirdiği sert politikalardır. Söz konusu politikalar Demokrat Parti kurucularına oldukça geniş politik bir manevra alanı sunmaktaydı. Çünkü partinin taşra

\footnotetext{
24 “Demokrat Parti Kongresinde İkinci Gün”, Tan, 22.06.1949.

25 "Hatipler Adalet Bakanına Şiddetle Hücum Ettiler", Zafer, 22.06.1949.

${ }^{26}$ BCA(Devlet Arşivleri Başkanlığı Cumhuriyet Arşivi), 490.100/204.808.2, "Celal Bayar'ın Mühim Nutku”, Tasvir, 21.06.1949; "Demokrat Parti İle Ne Alakanız Var", Zafer, 22.06.1949.

${ }^{27}$ BCA, 490.100/204.808.2, “Celal Bayar'ın Mühim Nutku”, Tasvir, 21.06.1949.

28 "Demokrat Partisinde", Akşsam, 25.03 1948; “Celal Bayar Bugün Şehrimizden geçerek Erzincan'a Gidiyor”, Ülke, 23.03.1948.

${ }_{29}$ BCA, 490.100/443.1832.1, “Celal Bayar'ın Dün İstanbul'da Yaptığı Mühim Konuşma”, Yeni Asır, 07.09.1948.

30 "Bayar Mecliste Muvazaa İsnadını Şiddetle Reddetti", Cumhuriyet, 23.02.1949; Hikmet Bayur, "Çeşme Söylevi" Kudret, 25.08.1948; "Demokrat Partinin Çeşme Mitingine Büyük Ehemmiyet Atfediliyor", Kudret, 18.08.1948.

${ }^{31}$ BCA, 490.100/443.1832.1, "Genel Başkan Umumi Seçimlere Nasıl Gidileceğini Anlatıyor", Demokrat İzmir, 07.09.1948; “Celal Bayar’ın Dün İstanbul’da Yaptığı Mühim Konuşma”, Yeni Asır, 07.09.1948
} 
teşkilatları iktidar mekanizmasından ve CHP teşkilatlarından yoğun baskı görmekteydiler. Taşradaki yer yer tedhişe varan bu uygulamalar muvazaa iddialarını zayıflatan bir unsur olmuştur. İktidarın bu politikalarının bazı somut örnekleri şunlardır: 21 Temmuz Seçimlerinden önce CHP Manisa Müfettişi Dr. Hulki Cura'nın Genel Sekreter N. Atıf Kansu'ya gönderdiği raporda yer alan "DP Ocak teşkilatlarından bazılarının üyelerinin tamamını istifaya muvafik olduklarını" ifade etmesi iktidarın yereldeki çalışmalarını açık etmektedir. ${ }^{32}$ Bu konuda çarpıcı bir örnek de 1946 Seçimlerinde milletvekili dahi seçilemeyen Sıtkı Yırcalı'nın 23 defa takibata maruz kalmasıdır. ${ }^{33}$ Bu gibi örneklere bir de parti içi muhalefetin iddialarının aksine iktidarın, muhalefeti ihtilal yöntemlerine başvurarak hukuk dışına çıkmakla suçlaması ${ }^{34}$ muvazaa iddialarını iyice dayanaksız kılmaktaydı.

Muvazaa iddialarını zayıflatan üçüncü unsuru ise DP kurucularının rasyonel bir hamleyle belediye seçimlerinin 1946 Eylülü’nde yapılması gerekirken mayısa çekilmesi üzerine seçimlere girmemesi oluşturur. Cumhurbaşkanı İsmet İnönü başta olmak üzere CHP yöneticilerinden gelen bütün baskılara rağmen ${ }^{35}$ bu kararın alınması muvazaa iddialarını boşa çıkaran en önemli unsur oldu. Bu karardan sonra Demokrat Parti'nin teşkilatlanmasındaki dramatik ilerleme göze çarpmaktadır. Bu konuda iktidar mekanizmasının baskılarının sınırlı olduğu İstanbul'da bile Demokrat Parti'nin teşkilatlanma rakamları çarpıcıdır. Demokrat Parti kurulduğu Ocak 1946 ve belediye seçimlerinin yapıldığı Mayıs 1946 arası dönemde İstanbul'da 16 ilçenin 6'sında 48 bucağın birkaçında örgütlenebilmiş iken belediye seçimlerinden 21 Temmuz 1946 Genel Seçimleri arasındaki yaklaşı 2 aylık sürede İstanbul genelinde teşkilatlanmasını tamamlamışıır. ${ }^{36} \mathrm{Bu}$ teşkilatlanma dalgası hızla Türkiye çapına yayılmış ve Nisan 1947'ye gelindiğinde Adnan Menderes, artık partisinin teşkilatlarını "yurt sathına yayılmış birer hürriyet mabedi" ş̧eklinde niteleyecektir. ${ }^{37}$ Ekim 1947'de Demokrat Parti Malatya gibi doğu illerinde de teşkilatlandığı Malatya Valiliği tarafından İçişleri Bakanlığına gönderilen 1/1157 sayılı rapordan anlaşılmaktadır. Buna göre, Refik Koraltan'ın ekim ayında gerçekleştirdiği Malatya gezisinden elde edilen malumatlardan hareketle Demokrat Parti'nin Malatya'da teşkilatlanmasını tamamlamıştı. ${ }^{38}$

Demokrat Parti'nin yurt sathında teşkilatlanması muvazaa isnatlarının boşa çıkarıldığı ve halkın muhalefet partisine teveccüh gösterdiğinin en önemli göstergesiydi. Buna karşın Demokrat Parti'nin muhalefet yıllarında muvazaa iddiaları hiçbir zaman bitmemiştir. Parti içi muhalefet Millet Partisi(MP) etrafında başka bir siyasal yapılanmaya gittikten sonrada bu suçlamalara devam etmiştir. Öyle ki bu Millet Partisi'nin kuruluş sebebini muvazaaya bağlamışlardır. Örneğin; Sadık Aldoğan, Kasım 1948 tarihli Sinop konuşmasında, Demokrat Parti'nin muvazaalı siyasetinden dolayı partiden ayrılıp MP'yi kurdukların ${ }^{39}$ ifade ederken, Sinop Milletvekili Suphi Batur ise aynı toplantıdaki konuşmasında DP'ye gerçek manada muhalefeti temsil ettiğine inandığı için katıldığını, ancak zamanla iktidarla muvazaa yaptığını görerek Millet Partisinde yer aldığını belirtmekteydi. ${ }^{40}$ Millet Partisi kurulduktan sonra da iktidara ve muhalefete karşı sert eleştirilere devam etti. Örneğin Mareşal, "samimi ve ivazsız

\footnotetext{
${ }^{32}$ BCA,490.100/443.1832.1. 08.08.1946.

${ }^{33}$ BCA, 010.09/39.116.1, 68. 02.08.1961.

34 “İki Parti Arasında Geçinme”, Ulus, 28.05.1948.

35"Demokrat parti İl Başkanı Belediye Seçimlerine İştirak Edilmesi Taraftarı Olduğunu Açıkladı", Cumhuriyet, 01.05 .1946 .

36 Öner, age, s. 22

${ }^{37}$ BCA, 030.01/12.79.8, 1. 21.04.1947.

${ }^{38}$ BCA, 030.01.65.407.7, 1. 06.10.1947.

${ }^{39} \mathrm{BCA}, 030.01 .66 .410 .4,1$. 04.11.1948.

${ }^{40} \mathrm{BCA}, 030.01 .66 .410 .4,2$. 04.11.1948.
} 
bir muhalefetten" 41 söz ederken Aldoğan, "Ne CHP ne de DP zimamdarlarl şefi ve şef sitemlerini ortadan kaldirmak istemiyorlar." özdeşleştirmeye çalışmaktaydı.

\section{Parti İçi İktidar Mücadelesi Bağlamında 12 Temmuz Beyannâmesi}

12 Temmuz Beyannâmesi, Türkiye'de çoğulcu demokratik sistemin kurulmasında en kritik değişkenlerden biri olmasının yanında Demokrat Parti'nin muhalefet yıllarında kuruculara karşı parti içinde geliştirilen politikaların en önemli araçlarından biridir. Bayar'ın ifadesiyle Demokrat Parti'nin siyasal hayatında "en çok söz mevzu olan hadise" 12 Temmuz Beyannâmesi olmuştur. ${ }^{43}$

Demokrat Parti'nin kendisi için iktidarın öngördüğü kontrollü muhalefet rolünü kabul etmeyeceğinin netleştiği 1946 yılının ortalarından itibaren iktidarın yoğun baskısına maruz kaldı. Buna karşı muhalefetin yer yer sert mukavemette bulunması politik ortamı iyice gerdi. 12 Temmuz Beyannâmesi'ne kadar söz konusu çatışmanın yoğunlaştığı başlıca konuları 21 Temmuz 1946 Genel Seçimlerinde uygulanan anti-demokratik yöntemler, İstanbul ve çevresinde uygulanan sıkıyönetimin uzatılması, Demokrat Parti I. Kongresi'nce ilan edilen iktidar partisinin anayasaya uymasını ve Cumhurbaşkanlığıyla parti başkanlığının ayrılması hükümlerini içeren Hürriyet Misakı ve Meclis'te Recep Peker'in Adnan Menderes'in hükümet bütçesini eleştiren konuşmasını "psikopat bir ruhun ifadeleri",44 şeklinde nitelemesiyle Demokrat Partililerin TBMM'den çekilmesi oluşturur.

1947 yılının Haziran ayına gelindiğinde Türkiye'de daha kurulma aşamasında olan demokratik çoğulcu sistem büyük bir kriz ve yok olma tehlikesiyle karşı karşıyaydı. Cumhurbaşkanı İnönü, müdahale etmezse iki parti arasındaki krizin çözülmesinin imkânsızlığının farkındaydı. Bu sebeple muhalefet partisi lideri Bayar ve Başbakan Peker ile önce ayrı ayrı daha sonra birlikte yaptığı bir dizi görüşme sonunda her iki Partiyi de "manevi sorumluluk" altında bırakan 12 Temmuz Beyannâmesi'ni yayımlamıştır. ${ }^{45}$ Beyannâmeyle iktidar muhalefete baskı yapmama, muhalefet hukuk içinde mücadele etme sözü veriyordu. ${ }^{46}$ İnönü’nün beyannâmeyle kendisini de sorumluluk altına soktuğu anlaşılmaktadır. Zira İnönü 12 Temmuz Beyannâmesi ile kamuoyuna partiler üstü kalma sözü vererek ${ }^{47}$ kendisini en azından biçimsel olarak tarafsız cumhurbaşkanı konumuna getirmiş oluyordu.

Beyannâme, her iki partide parti içi iktidar savaşlarına yol açtı. Partisi üzerinde büyük ağırlı̆gı olan İnönü, CHP'de muhalefete karşı tek parti politikalarıyla devam etmek isteyen Recep Peker'i 35'ler olayında görüldüğü gibi hizipçilik yapma pahasına da olsa tasfiye etmekte zorlanmadı. İnönü, Nihat Erim liderliğindeki genç hizbi harekete geçirerek Peker hükümetine 35 güvensizlik oyu verdirmiş bu sayı sonraki oylamada 47'ye yükselmiş, Peker'in parti başkan vekilliği teklifi de reddedilince 1947 Kurultayında genel başkanlığa aday olmuş sadece 25 oy

\footnotetext{
41 "Mareşalin Millete Beyannamesi”, Kudret, 22.07.1948.

${ }^{42}$ BCA, 490.100/443.1832.1 (tarih yok).

43 “Bayar Tenkitlere Mühim Bir Nutukla Cevap Verdi”, Yeni Sabah,24.06.1949; Mükerrem Sarol, Bilinmeyen Menderes, Cilt 1, Kervan Yayınları, İstanbul, 1983, s. 88.

44 Mahmut Goloğlu, Demokrasiye Geçiş, Türkiye İş Bankası Kültür Yayınları, İstanbul, 2013, s.172.

45 Türkiye Büyük Millet Meclisi Tutanak Dergisi (TBMMTD), Devre 8, Birleşim 1, Oturum 1, s. 8, 01.11.1949;

"Politikada Hareket ve Heyecanlı Bir Gün”, Cumhuriyet, 11.07.1947; “İnönü Başbakanla Tekrar Görüştü”, Cumhuriyet, 11.07.1947; Peker Kabinesinin İleri Demokrasisi”, Demokrat İzmir, 16.06.1947;"“Hükümetle Demokrat Parti Arasındaki İhtilaf", Cumhuriyet, 01.07.1947.

46 “İnönü’nün Beyanatı”, Ulus, 12.07.1947; “İnönü beyannâmesi”, Cumhuriyet, 12.07.1947.

47“İ̇önü Beyannâmesi”, Cumhuriyet, 12.07.1947;;’İönü'nün Demeci”, Cumhuriyet, 12.07.1947;”'Cumhurbaşkanı Millete Teminat Veriyor", Demokrat İzmir, 12.07.1947.
} 
alarak ağır bir hezimete uğramıştır. ${ }^{48}$ Böylece CHP'de radikal kanadı temsil eden Peker'in tasfiyesiyle Cumhurbaşkanı bütün partililere herkesin çoğulcu demokratik sistemin gerekliliklerini yerine getirilmesi gerektiği mesajını net olarak vermiş oluyordu.

Demokrat Parti'de ise beyannâmeye yaklaşım önce çok olumlu olmasına rağmen sonradan parti içi muhalefetin konuyu araçsallaştırmasıyla parti içi iktidar savaşının aracına dönüşmeye başlamıştır. Başlangıçta beyannâme Demokrat Parti'de bahar havası estirdi. Öyle ki; iktidar mekanizmasının muhalefet üzerindeki baskısını azalttığı için partinin bazı yerel teşkilatlarında beyannâmenin Celal Bayar'ın eseri olduğu kanaati hakimdi. ${ }^{49}$ Ancak 1947 sonbaharına gelindiğinde beyannâmenin partide yarattığı olumlu iklim dağılmaya başladı. Zira muhalif unsurlar artık 12 Temmuz Beyannâmesi'ni parti içi iktidar savaşının aracına dönüştürmeye başlayacaktır. Osman Bölükbaşı'nın istifası parti içi muhalefetin ilk hamlesiydi. Bölükbaşı 12 Temmuz Beyannâmesi'yle parti içindeki muhaliflerin başlarının İnönü’ye sunulduğunu iddia ediyordu. ${ }^{50} 1948$ yılının Ocak ayına gelindiğinde ise İstanbul İl Başkanı Kenan Öner'in Köprülü ve Menderes'in İstanbul teșkilatına müdahalelerine daha fazla dayanamayarak istifa etmesi ile parti içindeki iktidar mücadelesi iyice kızıştı. ${ }^{51}$ Şubat ve mart aylarında partiden ihraçlarla ${ }^{52}$ beyannâme artık parti içi muhalefet için söz konusu iktidar mücadelesinde kuruculara karşı kullanılacak temel araçlardan biridir.

Partinin radikal kanadını temsil eden muhalif unsurlar, özellikle partiden tasfiye edildikten sonra beyannâmeye yönelik sert eleştirilerde bulunmuşlardır. Bunlara göre halk hareketi olan Demokrat Parti, eski CHP'li kurucuların kabul ettiği 12 Temmuz Beyannâmesi'yle İnönü'ye teslim edilmişti. Fevzi Çakmak beyannâmeyi muvazaanın bir delili olarak kabul ederken ${ }^{53}$, Sadık Aldoğan'a göre bu beyannâme "İnönü beyannâmesiydi. ", ${ }^{\text {P4 }}$ Parti içi muhalefetin bütün tezlerini gönüllü olarak savunan eski Viyana Büyükelçisi Hamdi Arpag'ın Kudret gazetesi ise beyannâmeyi:"Kurucu denilen adamlar iktidar partisinden sirf kendi nefislerine zarar gelebileceğini düsünerek ve halkın demokrasi hareketindeki ciddiyetinden korkarak 12 Temmuz Beyannâmesi'ni kabul etmişlerdir",55 sözleriyle değerlendirmekteydi.

Kurucular ise beyannâmeyi iktidar partisiyle girdikleri siyasal yarışta elde edilen bir "eșitlik vesikası" olarak görmekteydiler. Köprülü, Kuvvet gazetesinde yayımlanan makalesinde beyannâmenin "memlekette hayat neşesi yaratacağl", düşüncelerine yer vermekteydi. Celal Bayar' da beyannâmenin reddiyle Demokrat Parti’nin hiçbir şey elde edemeyeceği gibi aksine

\footnotetext{
${ }^{48}$ Ergun Özbudun, Otoriter Rejimler, Seçimsel Demokrasiler ve Türkiye, İstanbul Bilgi Üniversitesi Yayınlar1, İstanbul, 2011, s.119; Emrullah Nutku, Demokrat Parti Neden Çöktü ve Politika'da Yitirdiğim Yıllar 1946-1948, Fakülteler Matbaası, İstanbul, 1979, s. 62; Cemal Anadol, Türk Siyaset Tarihinde Demokrat Parti, Yeni Kuvay1 Milliye Yayınları, İstanbul, 2003, s. 60.

${ }^{49}$ BCA, 490.10/165.658.1, 8. 21.07.1947.

${ }^{50}$ Osman Bölükbaşı, Suikast İftirasının İçü̈zü ve Celal Bayar, Ankara, 1949, 5.

51 "Kenan Öner'in İstifaname Sureti Basına Verildi", Cumhuriyet, 12.02.1948; "Kenan Öner'in İstifası", Yeni Sabah, 08.01.1948.

52 "Demokrat Partide Buhran ", Akşam, 08.02.1948; Demokrat Partide Tasfiye Başladı", Tasvir, 11.03.1948; "Demokrat Partide Tasfiye Başladı", Cumhuriyet, 11.03.1948; "DP'den Çıkarılan Millet Vekilleri”, Yeni Sabah, 11.03.1948; "Yeni Parti İçin Henüz Teşebbüs Yok" , Akşam 11.03.1948; "D.P. Haysiyet Divanı Kararı", Kudret, 11.03.1948.

${ }_{53}^{53}$ Ăaoğlu, Siyasi Günlük: Demokrat Partinin Kuruluşu, s. 12.

54 “Inönü Beyannâmesi ve Demokratlar", Yeni Sabah, 19.02.1948.

55“"D. Parti Büyük Kongresi Açıldı", Kudret, 21.05.1948.

56 “Demokrat Partiyi Y1kmaya İmkân Yoktur”, Kudret, 09.02.1948.
}

\section{History Studies}


iktidara muhalefetin eşit şartlarda yarışmayı reddettiği yönünde propaganda yapma firsatı doğacağını ifade etmekteydi. ${ }^{57}$

Demokrat Partide 12 Temmuz Beyannâmesi'nin merkezinde yer aldığ iktidar savaşını kurucular kazanmıştır. Beyannâmeyi araçsallaştıran radikal kanat, partinin yönetim kurullarını ve yerel teşkilatlarını yanlarına çekemedikleri gibi parti kitlesinde de ciddi bir siyasal dalgalanma yaratamamışlardır. Kurucuların bu başarısında şu faktörler önemli rol oynamıştır; birincisi; Bayar'ın 22 Temmuz 1947 günü illerden gelen delegeler, 17 milletvekili ve Genel İdare Kurulu üyelerinin katılımıyla 150 kişiyle "küçük istişari kongreyi" toplayarak 12 Temmuz Beyannâmesi'ni bu kongreye kabul ettirmesidir. ${ }^{58}$ Böylece beyannâme kurucuların kabul ettiği bir metin olmaktan çıkmış, delegelerin, partinin büyük kongreden sonra en yetkili organı olan GİK ve Meclis Grubu'ndan üyelerin kabul ettiği bir belgeye dönüşmüş ve partiye mal olmuştur.

Bu konuda kurucuların başarısında etkili olan ikinci etken ise sonradan beyannâmeye ağır eleştiren getiren muhaliflerin ilk başta Genel İdare Kurulu'nda beyannâmenin kabulü yönünde oy kullanmalarıdır. 12 Temmuz Beyannâmesi'nin GÍK’teki görüşmelerinde Yusuf Kemal Tengirşenk'in dışındaki, Celal Bayar, Adnan Menderes, Fuat Köprülü, Refik Koraltan, Samet Ağaoğlu, R. Şevket İnce, Ahmet Oğuz, Ahmet Tahtakılıç, Enis Akaygen, Cemal Tunca, F. Lütfi Karaosmanoğlu, ve Hasan Dinçer'den oluşan diğer üyelerin tamamının leyhte oylarıyla ve beyannâmenin sonuna "beyanatın neşrinden önce başbakanla muhalif parti lideri görmüşlerdir" şerhinin düşülmesi şartıyla kabul edilmiştir. ${ }^{59}$ Sonradan 12 Temmuz Beyannâmesi'ni araçsallaştırarak kuruculara karşı amansız mücadeleye başlayacak Ahmet Tahtakılıç, Ahmet Oğuz ve Enis Akaygen gibi muhalif unsurların başlangıçta beyannâme karşısındaki olumlu yaklaşımları Demokrat Parti kitlesinin gözünden kaçmayacak ve bu kişilerin paradoksal yaklaşımları parti tabanından teveccüh görmeyecektir.

Üçüncüsü, Partinin yerel teşkilatları 12 Temmuz Beyannâmesi'nin kendi faaliyetlerinde sağladığı kolaylığı yaşayarak müşahede etmekteydiler. Beyannâmeden önce DP'ye üye olmanın ve faal rol almanın ciddi bir tehlike ${ }^{60}$ oluşturduğu birkaç ay öncesini unutmamışlard. Bunun sonucu olarak da parti içi muhalefetin siyasal gerçeklikten uzak söylemlerine iltifat etmek yerine iktidarla siyasal rasyonalite temelinde mücadeleyi savunan kurucuların peşinden gitmeyi tercih ettiler.

Kurucuların başarısında etkili olan son faktör ise muhalif unsurların Bayar'ın gayet sade bir şekilde dile getirdiği "Beyannâmeyi kaybetmekle ne kazanacaktık?"61 sorusuna hiçbir platformda Demokrat Parti kitlesini ikna edecek rasyonel cevap verememeleridir. Muhalif unsurlar bu konuda üst perdeden ve siyasal gerçeklikten kopuk retoriği yüksek polemiklerle Demokrat Parti tabanını kazanabilecekleri yanılgısını aşamamışlardır.

\section{Parti İçi İktidar Mücadelesi Bağlamında Demokrat Parti Kurucularının Siyasal Geçmişleri}

Demokrat Parti kurucuları siyasal sosyalizasyonlarını CHP'ye borçludurlar. Tek parti yönetiminin yürütme, yargı ve yasama erklerinde yıllarca çeşitli görevlerde bulunmuşlardır. Celal Bayar, Demokrat Parti'nin kuruluşunda basına yaptığı açıklamada tek parti dönemindeki

\footnotetext{
${ }^{57}$ BCA, 490.100/204.808.2, “Celal Bayar'ın Mühim Nutku”, Tasvir, 21.06.1949.

58 "DP Genel Merkezinde Toplantılar Başladı", Cumhuriyet, 28.07.1947.

59 "Demokrat Parti Genel İdare Kurulu'nun 18 Sayılı Kararı", Ağaoğlu, Siyasi Günlük: Demokrat Partinin Kuruluşu, 444.

${ }^{60}$ BCA, 490.100/204.808.2, “Celal Bayar'ın Mühim Nutku”, Tasvir, 21.06.1949.

${ }^{61}$ BCA, 490.100/204.808.2, “Celal Bayar'1n Mühim Nutku”, Tasvir, 21.06.1949; Sarol, age, s. 90.
} 
uygulamaların sorumluluğundan da kaçmayan bir yaklaşımla bu olguyu şöyle tespit etmektedir: Şeref ve mesuliyetleri ile mazi hepimizindir. Ne yapılmıssa iyi niyetle ve inkılabı kurmak ve korumak için yapılmış ve bence zamanın en mükemmel tedbirleri alınmıştır fakat yeni bir devir gelmiştir ve bu devrin işlerini devrin zihniyetiyle yürütmek zamanı gelmiştir. Mazinin mesuliyetleri varsa bizim hisselerimiz şunun bunun mesuliyetinden az değildir. "62

Parti içi muhalefetin, kurucuların CHP geçmişlerini nasıl araçsallaştırdığına geçmeden kurucuların Demokrat Parti öncesi siyasi kariyerlerine göz atmak sonraki değerlendirmelere zemin oluşturacaktır. Celal Bayar, 1920 Genel Seçimlerinden başlayarak her dönem CHP milletvekilidir. 1920 yılında Manisa, 1923-1946 arası ise İzmir Milletvekilliği yapmıştır. Şubat 1921'de Ekonomi Bakanlığı yapmış, 6 Şubat 1922-2 Nisan 1922 arası Dışişleri Bakanlığına vekâlet etmiş̧tir. 11 Eylül 1923'te Halk Fırkası yönetim kuruluna seçilen Bayar, 16 Mart 1924 tarihinde II. İnönü hükümetinin Mübadele İmar ve İskân Bakanı olmuştur. 1924'te Atatürk tarafından İş Bankası'nı kurmak ve yönetmekle görevlendirilmiştir. Bu atama İnönü'yle rekabetinin de başlangıcı oldu. 1932 yılında ekonomi bakanlığına getirilen Bayar, 1937 sonbaharında başbakanlığa ve CHP genel başkan vekilliğine getirilmiş ve Atatürk’ten sonra ikinci adam olmuştur. A tatürk'ün ölümünden sonra Cumhurbaşkanı seçilen İnönü'nün ssrarıyla üç ay daha başbakanlık görevini sürdürmüştür. ${ }^{63}$ Demokrat Parti'nin kuruluşunun hemen öncesine tekabül eden 2 Aralık 1945 tarihine kadar CHP üyeliğini sürdürmüştür. ${ }^{64}$

Adnan Menderes, siyasete SCF Aydın il başkanı olarak atılmış bu partinin kendini feshetmesinden sonra CHP'ye katılmıştır. Aydın ziyaretinde Atatürk'ü ciddi şekilde etkileyerek Atatürk'ün önerisiyle 1931 seçimlerinde CHP'den Aydın milletvekili seçilmiştir. Daha sonra y1llarca parti müfettişliği de yapacak olan Menderes, 1935, 1939 ve 1943 Genel Seçimlerinde değişmez Aydın milletvekilidir. ${ }^{65}$

Fuat Köprülü, tek parti döneminde 1935, 1939 ve 1943 yıllarında Kars milletvekilliği yapmıştır. 24 yaşında Milli Eğitim Bakanlığı Müsteşarı olmuşs6, daha sonra Halk Evleri’nin yayın organı Ülkü dergisinde yayın yönetmenliği yapmıştır.

Refik Koraltan, tek parti döneminde sirasiyla Artvin, Trabzon, Bursa valilikleri yaptı. Yozgat ve İstanbul İstiklal Mahkemesi üyeliklerinde bulundu. Tek parti meclislerinde Konya ve İçel milletvekilliği yaptı. ${ }^{67}$

Demokrat Parti kurucularının yukarıda kısaca özetlenen tek partideki siyasal kariyerleri parti içi muhalefet tarafından sürekli araçsallaştırılan unsurlardan biri oldu. Bu konuda birkaç örnek şöyledir; Parti içi muhalefetin önde gelen isimlerinden Osman Bölükbaşı, kurucuları " $D$. parti lideri zemzemle ylkanıp gökten inmediler, bu şahıslar $H$. Partisi zamanında $H$. Partililerin saflarında tokmaklarının sapını tutuyorlardı "68 şeklinde eleştirmekteydi. Demokrat

\footnotetext{
${ }^{62}$ Cağfer Güler, "Türkiye'de Çok Partili Düzene Geçişte(1945-1950) Serbest Fırka Deneyiminin İzleri”. TAD, Cilt 34, S.57, 2015, S. 303.

${ }^{63}$ George Harris, "Celal Bayar”, (ed. Sabri Sayarı, ve Metin Heper), Türkiye 'de Liderler ve Demokrasi, (Çev. Zuhal Bilgin), Kitap Yayınevi, İstanbul, 2008, s.57; Akif Usluy, Kırkaltı Ruhu, Onur Kitap, İstanbul, 2012, s. 183; İsmet Bozdağ, Bilinmeyen Atatürk :Celal Bayar Anlatıyor, Truva Yayınları, İstanbul, 2005, s.97-98.

${ }^{64}$ TBMMTD, Birleşim 2, Oturum 1, 5.11.1945, s.14; "C. Bayar'ın Milletvekilliğinden İstifası Haberi Doğru Çıktı", Vatan, 29.09.1945.

${ }^{65}$ Sabri Sayarı, “Adnan Menderes”, (ed. Sabri Sayarı ve Metin Heper), Türkiye’de Liderler ve Demokrasi, ( Çev. Zuhal Bilgin), Kitap Yayınevi, İstanbul, s. 79; Şevket Süreyya Aydemir, Menderesin Dramı, Remzi Kitabevi, İstanbul, 2014, s.90.

${ }^{66}$ Serhan Yücel, Demokrat Parti, Ülke Kitapları, İstanbul, 2001, 45.

${ }^{67}$ Refik Koraltan, Tek Parti Devrinden 27 Mayls İhtilaline Demokratlar DP'nin Kurucusu Anlatıyor, (der. Kamil Maman), Timaş Yayınları, İstanbul, 2013, s. 31.

${ }^{68}$ BCA, 030.01/46.275.5, 3. 19.06.1955.
} 
Parti'den Şubat 1948 'de ihraç edilen Muğla milletvekili Mithat Sakaroğlu ise kurucuları, tek parti zihniyetine sahip olmakla ve İstibdat, Meşrutiyet ve Cumhuriyet dönemlerinde her zaman iktidarın yanında yer almakla suçluyordu. ${ }^{69}$ Demokrat Parti'de parti merkez yönetimine karş1 ilk bayrağı açan ve partiden ihraç edilen Demokrat Parti İzmir Teşkilatı'nın etkili hatiplerinden Mustafa Kentli de kurucuların siyasal geçmişlerine çeşitli suçlamalarla yüklü şu eleştirileri yapmaktaydı:"Liderler halkın kanuni yollardan CHP'yi devirme amacını anlayamadılar çünkü onlarda otoriter ve totaliter bir siyasi mektebin izlerini taşıyorlardl. Mühim olan halk değil halkın şuurlu kesiminin düşünceleriydi. Bu sebeple parti içi gayet sert taarruza geçtiler. Partili birçok kişiyi hayal kırıklığına uğrattılar çünkü demokrasi ve hürriyet prensiplerini ülkeye getirmek için yola çıkan kimselerden öncelikle bunu kendi partilerinde uygulamaları beklenirdi. Fakat bunu yapmaları aldıkları siyasi terbiye bakımından çok güçtü. DP liderleri hürriyet yerine kurucuların otoritesini ve sikı disiplini esas aldılar."

Demokrat Parti'nin Afyon Milletvekili General Sadık Aldoğan da kurucuları tek parti alışkanlıklarını Demokrat Parti'ye taşıdıkları gerekçesiyle şöyle eleştirmekteydi: "Tenkit hürriyeti kaldırıldığl gün dört buçuk adamın fikri tahakkümü altında bir parti çöker.,"71

CHP'li geçmişleri parti içi muhalefet tarafından sürekli araçlaştırılmasına karşın şu üç olgusal gerçek kurucuların bu müşgülü aşmasında etkili olmuştur: İlk olarak bütün kamuoyu ve Demokrat Parti tabanı da tek parti döneminde CHP dışında herhangi bir yerde siyaset yapabilmenin imkânının söz konusu olmadığının farkındaydı. Samet Ağaoğlu durumu şöyle tespit etmektedir: DP içinde onu kuranlardan başlayarak sayıları yüzbinleri aşan vatandaşların eski halk partililer olduğu hiçbir zaman inkâr edilmediği gibi zaten başka türlü olmasina da imkân yoktur. "72

İkincisi; Bayar dışındaki diğer üç kurucu ismin tek parti yönetiminde öne çıkan isimler olmamasıdır. Bu üç isim CHP'nin parti politikalarının belirlenmesinde ya da idare mekanizmasında temel karar alıcılar olan birinci halkanın içinde hiçbir zaman yer alamadılar. Bu bağlamda şu örnek çarpıcıdır: Demokrat Parti'nin muhalefet yıllarında parti sözcüsü iktidar yıllarında başbakan olarak güçlü hitabetiyle dikkat çeken Menderes'in, 1945 yılına kadar Meclis'te toplam 23 dakikalık iki konuşma yapmış olmasıdır. ${ }^{73}$

Son olarak Bayar'ın İnönü tarafından güvenilir kişiliğine karşın üç özelliği Demokrat Parti yerel teşkilatları ve tabanının kurucuların yanında yer almasını sağlamıştır. Birincisi; Atatürk'ün özel önem verdiği bir isim olması ve üst düzey görevlerde yer alması dolayısıyla sahip olduğu devlet tecrübesidir. İkincisi; İnönü'yle özellikle ekonomi politikaları konusunda CHP içindeki geleneksel rekabetidir. Zira İnönü devletçi ekonomiden yana bir siyasal çizgiye sahipken Bayar karma ekonomik modeli savunan gelen bir siyasetçiydi. Üçüncüsü; Atatürk’ün ölümünden üç ay sonra başbakanlıktan ayrılarak CHP içinde muhalefet odağı haline gelmesidir. Bu bağlamda Bayar'ın 1944 bütçe oylamasında tek hayır oyunun sahibi olduğu ${ }^{74}$ ve İnönü'nün, CHP'nin genel başkan vekilliği teklifini reddettiği ve Müstakil Grup liderliğini istediği bilinmekteydi. Bütün bunlardan dolayı Bayar, zaten kamuoyunda hizipçilerin baş1 olarak görülmekteydi.

\footnotetext{
69،"Ahmet Kemal Silivrili 'den Sonra Bir DP Milletvekili Daha İtham Ediyor.”, Yeni Sabah, 26.02.1948.

${ }^{70}$ Mustafa Kentli, "DP'de Buhranın sebepleri “, Yeni Sabah, 01.04.1948.

71 “5 Milletvekili DP'den İhraç Edildi. Yeni Sabah 11.03.1948”; "D.P. Meclis Grubunda Seçim Dün Yapıldı”, Kudret, 12.02 .1948 .

${ }^{72}$ BCA, 490.01/204.808.4. 10.09.1950.

${ }^{73}$ Yücel, age, s. 46.

${ }^{74}$ TBMMTD, Devre 7, İnkıta 1, Cilt 10, s.422, 29.05.1944.
} 


\section{Sonuc}

Liberal aydınlardan ticaret burjuvazisine, muhafazakar eşraftan CHP iktidarında istediği bürokratik mevkilere gelemeyenlere kadar farklı sınıflara, ideolojilere sahip geniş bir koalisyon olarak teşekkül eden Demokrat Parti'de parti içi muhalefetin ortaya çıkması kaçınılmazdı. Özellikle anti-demokratik 21 Temmuz 1946 Genel Seçimlerinden sonra partinin meclisten çekilerek sine-i millete dönmesi gerektiğini savunan bir grubun ortaya çıkmasıyla parti içi muhalefet iyice görünür olmaya başlamıştır. Türkiye'nin o dönem aktüel politik ikliminin de sağladığı avantajla parti içinde her konuyu araçsallaştırma noktasında oldukça mahir olan parti içi muhalefetin, Demokrat Parti'nin muhalefet yıllarını işaret eden 1946-1950 yılları arasındaki argümanları, kurucuların siyasal geçmişleri, muvazaa iddiaları ve 12 Temmuz Beyannâmesi olmuştur.

Demokrat Parti'nin yurt çapında teşkilatlanmasını büyük oranda tamamlayarak iktidar seçeneği olarak ortaya çıkmaya başladığı 1948 yılı başları aynı zamanda parti içi iktidar savaşının da şiddetlendiği bir kesiti işaret etmekteydi. Parti içinde siyasal mücadelenin tam bir çatışmaya dönüştüğü bu tarihten itibaren parti içi muhalefette sahip olduğu araçları daha yoğun kullanmaya başlayacaktır. Bu bağlamda şu çıkarımlar yapılabilir: Birincisi, parti içi muhalefet kurucuların siyasal geçmişlerini araçsallaştırarak parti içi iktidarı ele geçirme noktasında herhangi bir siyasal başarı elde edememiştir. Demokrat Parti yerel teşkilatları ve tabanı oldukça makul davranarak parti kurucularının tek parti döneminde CHP dışında bir yerde siyaset yapma olanaklarının olmadığını hiçbir zaman göz ardı etmemiş ve muhalif unsurların, kurucuların CHP'deki otoriter anlayışı ve zümre hâkimiyetini Demokrat Parti'ye taşıdıkları iddialarını dikkate almamışlardır. Söz konusu iddia merkezde parti içi iktidarı ele geçirmenin bir aracı olarak kalmıştır.

İkincisi, 12 Temmuz Beyannâmesi başlangıçta Demokrat Parti'de iktidarla eşit koşullarda siyasal faaliyet yürütmenin aracı olarak görülerek oldukça olumlu karşılanmasına rağmen daha sonra parti içi muhalefet tarafindan kurucuların İnönü ile anlaşmasının bir vesikası olarak kurgulanarak araçsallaştırılmıştır. Demokrat Parti'nin iktidara geldiği 1950 genel seçimlerine kadar parti içi muhalefetin vazgeçilmez argümanlarından biri olmuştur.

Üçüncüsü, Muvazaa iddiaları Demokrat Parti'nin muhalefet yılları boyunca parti merkez yönetimini en çok zorlayan konu olmuştur. Türk siyasal tarihinde SCF deneyimi gibi nesnel bir karşılı̆̆ının olması ve iç politik konjonktürün İnönü’nün hoş görüsünü zorunlu kılması gibi sebeplerle kurucuların, İnönü'yle eş güdüm halinde politikalar geliştirme zorunluluğu muvazaa kaygılarını beslemiştir. Ancak parti içi muhalefetin "siyaset esnaflığı" olarak tanımlanabilecek siyasal gerçeklikten kopuk retoriği yüksek konuşmalarla Demokrat Parti kitlesini kazanma amacı taşıyan yaklaşımları, partinin yerel teşkilatlarından ve geniş kitlesinden ciddi bir karşıllık görmemiştir.

Son olarak parti içi muhalefetin başarısızlığı söz konusu edildiğinde yapılması gereken bir çıkarım da; kurucuların rasyonel stratejilerinin bu başarısızlıkta oynadığı role yöneliktir. Bu bağlamda Bayar başta olmak üzere kurucular, parti içindeki muhalif unsurları başarıyla iktidar ile özdeşleştirmişlerdir. Demokrat Parti içindeki ayrılık yaratanların iktidarın hedeflerine hizmet ettikleri tezini başarıyla işlemişler ve partinin yerel teşkilatlarıyla yaptıkları toplantılar, mitingler, basın yoluyla partinin bütün kademelerine ve partinin geniş kitlelerine bunu kabul ettirmişlerdir. 


\author{
Kaynakça \\ Başbakanlık Cumhuriyet Arşivi \\ BCA, 490.100/204.808.2, 21.06.1949. \\ BCA, 490.100/443.1832.1, 07.09.1948. \\ BCA, 490.100/443.1832.1. 08.08.1946. \\ BCA, 010.09/39.116.1, 68. 02.08.1961. \\ BCA, 030.01/12.79.8, 1. 21.04.1947. \\ BCA, 030.01.65.407.7, 1. 06.10.1947. \\ BCA, 030.01/46.275.5, 3. 19.06.1955. \\ BCA, 030.01.66.410.4,1. 04.11.1948. \\ BCA, 490.10/165.658.1, 8. 21.07.1947. \\ BCA, 490.01/204.808.4. 10.09.1950. \\ BCA, 490.100/443.1832.1 (tarih yok).
}

Türkiye Büyük Millet Meclisi Tutanak Dergisi (TBMMTD),

TBMMTD, Devre 8, Birleşim 1, Oturum 1, s. 8, 01.11.1949.

TBMMTD, Birleşim 2, Oturum 1, 5.11.1945.

TBMMTD, Devre 7, İnkita 1, Cilt 10, 29.05.1944.

\title{
Gazete Haberleri
}

"5 Milletvekili DP'den İhraç Edildi. Yeni Sabah 11.03.1948.

“Ahmet Kemal Silivrili 'den Sonra Bir DP Milletvekili Daha İtham Ediyor.", Yeni Sabah, 26.02.1948.

"Bayar Mecliste Muvazaa İsnadını Şiddetle Reddetti", Cumhuriyet, 23.02.1949.

"Bayar Tenkitlere Mühim Bir Nutukla Cevap Verdi", Yeni Sabah,24.06.1949.

“C. Bayar'ın Milletvekilliğinden İstifası Haberi Doğru Çıktı”, Vatan, 29.09.1945.

"Celal Bayar Bugün Şehrimizden geçerek Erzincan'a Gidiyor”, Ülke, 23.03.1948.

“Celal Bayar'ın Dün İstanbul'da Yaptığı Mühim Konuşma”, Yeni Asır, 07.09.1948.

“Celal Bayar'ın Mühim Nutku”, Tasvir, 21.06.1949.

"Cumhurbaşkanı Millete Teminat Veriyor", Demokrat İzmir, 12.07.1947.

"D. Parti Büyük Kongresi Açıldı”, Kudret, 21.05.1948.

"D.P. Haysiyet Divanı Karar1”, Kudret, 11.03.1948.

“D.P. Meclis Grubunda Seçim Dün Yapıldı”, Kudret, 12.02.1948.

"Demokrat Parti İle Ne Alakanız Var", Zafer, 22.06.1949.

"Demokrat Parti İşe Başlamadan", Ulus, 18.01.1946.

"Demokrat Parti Kongresinde İkinci Gün”, Tan, 22.06.1949.

"Demokrat Parti", Tasvir, 03.04.1948.

"Demokrat Partide Buhran ", Akşam, 08.02.1948.

"Demokrat Partide Buhran ", Akşam, 08.02.1948.

"Demokrat Partide Tasfiye Başladı", Cumhuriyet, 11.03.1948.

"Demokrat Partisinde", Akşam, 25.031948.

"Demokrat Partiyi Y1kmaya İmkân Yoktur", Kudret, 09.02.1948.

"DP Genel Merkezinde Toplantılar Başladı”, Cumhuriyet, 28.07.1947.

"DP Meclis Grubu Dün Toplandı”, Cumhuriyet, 07.08.1946.

"DP'de Buhranın sebepleri “, Yeni Sabah, 01.04.1948.

"DP'den Çıkarılan Millet Vekilleri”, Yeni Sabah, 11.03.1948.

"Genel Başkan Umumi Seçimlere Nasıl Gidileceğini Anlatıyor", Demokrat İzmir, 07.09.1948.

"Hatipler Adalet Bakanına Şiddetle Hücum Ettiler", Zafer, 22.06.1949.

"Hikmet Bayur Hamdullah S. Tanrı̈vere Cevap Veriyor", Kudret, 26.08.1948.

"Hükümetle Demokrat Parti Arasındaki İhtilaf", Cumhuriyet, 01.07.1947.

"İki Parti Arasında Geçinme”, Ulus, 28.05.1948. 
“İki Partiyi Uzlaştırma Teşebbüsü Şayiaları”, Cumhuriyet, 07.08.1946.

“İnönü Başbakanla Tekrar Görüştü”, Cumhuriyet, 11.07.1947.

“İnönü Beyannâmesi ve Demokratlar”, Yeni Sabah, 19.02.1948.

“İnönü beyannâmesi”, Cumhuriyet, 12.07.1947.

“İnönü’nün Beyanatı”, Ulus, 12.07.1947.

“İnönü'nün Demeci”, Cumhuriyet, 12.07.1947.

"Kenan Öner'in İstifaname Sureti Basına Verildi", Cumhuriyet, 12.02.1948;

"Kenan Öner'in İstifası", Yeni Sabah, 08.01.1948.

"Muvazaa İddiasina Dair", Ulus, 04.09.1948.

"Muvazaayı Doğuran Amil Nedir”, Kudret, 28.08.1948.

"Peker Kabinesinin İleri Demokrasisi”, Demokrat İzmir, 16.06.1947.

"Politikada Hareket ve Heyecanlı Bir Gün”, Cumhuriyet, 11.07.1947.

"Yeni Parti İçin Henüz Teşebbüs Yok", Akşam 11.03.1948.

Araştırma Eserleri

AĞAOĞLU, Samet, Siyasi Günlük: Demokrat Partinin Kuruluşu, (yay. haz. Cemil Koçak), İletişim Yayınları, İstanbul, 2013.

AĞAOĞLU, Samet, Aşina Yüzler, Yapı Kredi Yayınları, İstanbul, 2011.

ANADOL, Cemal, Türk Siyaset Tarihinde Demokrat Parti, Yeni Kuvayı Milliye Yayınları, İstanbul, 2003.

AYDEMİ, Ş. Süreyya, Menderesin Dramı, Remzi Kitabevi, İstanbul, 2014.

BABAN, Cihat, Politika Galerisi, Timaş Yayınları, İstanbul, 2009.

BOZDAĞ, İsmet, Bilinmeyen Atatürk :Celal Bayar Anlattyor, Truva Yayınları, İstanbul, 2005.

BÖLÜKBAŞI, Osman, Suikast İftirasının İçyüzü ve Celal Bayar, Ankara, 1949.

CERRAHOĞLU, P. Bigat, Demokrat Parti Masall, Milliyet Yayınları, İstanbul, 1996.

DUVERGER, Maurice, Siyasal Partiler, (Çev. Ergun Özbudun), Bilgi Yayınevi, İstanbul, 1974.

EROĞUL, Cem, Demokrat Parti Tarihi ve İdeolojisi, Yordam Kitap, İstanbul, 2014.

GOLOĞLU, Mahmut, Demokrasiye Geçiş, Türkiye İş Bankası Kültür Yayınları, İstanbul, 2013.

GÜLER, Cağfer, “Türkiye’de Çok Partili Düzene Geçişte(1945-1950) Serbest Firka Deneyiminin İzleri”. TAD, Cilt 34, S.57, 2015, 291-315.

HARRIS, George, "Celal Bayar", (ed. Sabri Sayarı ve Metin Heper), Türkiye'de Liderler ve Demokrasi, (Çev. Zuhal Bilgin), Kitap Yayınevi, İstanbul, 2008, 55-76.

HAYTOĞLU, Ercan, "İnönü Döneminde Türkiye'de Siyasal Yaşam”, (ed. Süleyman İnan ve Ercan Haytoğlu), Yakın Dönem Türk Politik Tarihi, Ankara, 2011, 77-115.

HEPER, Metin, Türkiye'nin Siyasal Hayatı, Doğan Kitap, İstanbul, 2011.

HEYWOOD, Andrew, Siyaset, (Çev. B. Özipek, B. Şahin, M. Yıldız, Z. Kopuzlu, B. Seçilmişoğlu, A.Yayla), Adres Yayınları, Ankara, 2013.

KORALTAN, Refik, Tek Parti Devrinden 27 Mayls İhtilaline Demokratlar DP'nin Kurucusu Anlatıyor, (der. Kamil Maman), Timaş Yayınları, İstanbul, 2013.

METE, Orhan, Bütün Tafsilat ve Akisleriyle Demokrat Parti'nin 1'nci Büyük Kongresi 7 Ocak 1947, Ticaret Dünyas1 Matbaas1, İstanbul, 1947.

NUTKU, Emrullah, Demokrat Parti Neden Çöktü ve Politika'da Yitirdiğim Yıllar 1946-1948, Fakülteler Matbaası, İstanbul, 1979.

ÖNER, Kenan, Siyasi Hatıralarım ve Bizde Demokrasi, Osmanbey Matbaası, İstanbul, 1948.

ÖZBUDUN, Ergun, Otoriter Rejimler, Seçimsel Demokrasiler ve Türkiye, İstanbul Bilgi Üniversitesi Yayınları, İstanbul, 2011. 
PANCAROĞLU, A. F., Yakın Tarihimizde Millet Partisi Olgusu(1948-1977), Yayınlanmamış Yüksek Lisans Tezi, Afyonkarahisar Kocatepe Üniversitesi, 2006.

SAÇLIOĞLU, Nahit, Bir Özgürlük Savaşçısı: Sadık Aldoğan, 1990.

SAROL, Mükerrem, Bilinmeyen Menderes, Cilt 1, Kervan Yayınları, İstanbul, 1983.

SAYARI, Sabri, “Adnan Menderes", (ed. Sabri Sayarı ve Metin Heper), Türkiye'de Liderler ve Demokrasi, (Çev. Zuhal Bilgin), Kitap Yayınevi, İstanbul, 2008,

TOKER, Metin, Tek Partiden Çok Partiye (1944-1950), Bilgi Yayınevi, Ankara, 1998.

TOSUN, Tanju -TOSUN, Gülgün Erdoğan, Türkiye'de Siyasal Parti Üyeliği ve Katılım, Kalkedon Yayıncılık, İstanbul, 2010.

USLUY, Akif, Kırkaltı Ruhu, Onur Kitap, İstanbul, 2012.

YÜCEL, Serhan, Demokrat Parti, İstanbul: Ülke Kitapları, 2001. 